\title{
Rapid fecal calprotectin testing predicts mucosal healing better than C-reactive protein and serum tumor necrosis factor $\alpha$ in patients with ulcerative colitis
}

\author{
T. VOIOSU ${ }^{1,2}$, ANDREEA BENGUŞ̧ $^{1}$, P. BĂLĂNESCU ${ }^{1,2}$, ROXANA DINU $^{1}$, \\ A. VOIOSU ${ }^{1,2}$, C. BĂICUŞ ${ }^{1,3}$, B. MATEESCU ${ }^{1,2}$ \\ 'Gastroenterology Division, "Colentina” Clinical Hospital, 19-21 Ștefan cel Mare Bvd., Bucharest, Romania \\ ${ }^{2}$ UMF Carol Davila School of Medicine, Eroii Sanitari Bvd., Bucharest, Romania \\ ${ }^{3}$ Internal Medicine Division, "Colentina” Clinical Hospital, 19-21 Ştefan cel Mare Bvd., Bucharest, Romania
}

\begin{abstract}
Background and Aims. Serum and fecal biomarkers have been used as noninvasive methods for assessing disease activity in ulcerative colitis. C-reactive protein, serum tumor necrosis factor- $\alpha$ and fecal calprotectin are among the most promising such biomarkers. However, their role in the management of ulcerative colitis patients remains to be clarified. We aimed to evaluate the accuracy of C-reactive protein, fecal calprotectin and tumor necrosis factor- $\alpha$ in detecting clinical and endoscopic activity and predicting disease outcome.

Methods. A cohort of ulcerative colitis patients was prospectively evaluated for clinical and endoscopic disease activity using the Mayo score. Serum C-reactive protein and tumor necrosis factor$\alpha$ levels were measured and a point-of-care method was used for determining Calprotectin levels.

Results. Fifty-three patients with ulcerative colitis were followed for a median of 12 months. Fecal calprotectin and C-reactive protein levels were significantly higher in patients with clinically active disease at baseline, but only calprotectin levels correlated with endoscopic activity. Calprotectin values over $300 \mu \mathrm{g} / \mathrm{g}$ had $60 \%$ sensitivity and $90 \%$ specificity for detecting active endoscopic disease and $61 \%$ sensitivity and $89 \%$ specificity for predicting mucosal healing.

Conclusion. Rapid calprotectin testing is a better predictor of mucosal healing than serum biomarkers and it could improve the management of ulcerative colitis patients by decreasing the need for invasive investigations.
\end{abstract}

Key words: ulcerative colitis, fecal calprotectin, C-reactive protein, mucosal healing.

\section{INTRODUCTION}

Serum and fecal biomarkers have emerged as important noninvasive tools in the workup of inflammatory bowel disease (IBD) patients $[1,2]$. The purpose behind developing accessible tests for the diagnosis and monitoring of IBD is to minimize the need for cumbersome and invasive investigations such as colonoscopy. As a result, most studies have focused on the relationship between biomarker levels and clinical and endoscopic disease activity in order to improve accuracy in the diagnosis of IBD.

C-reactive protein (CRP) and fecal calprotectin (FC) are among the most promising and intensely studied biomarkers, showing good diagnostic and prognostic accuracy in IBD [3-5]. The expanding role of such noninvasive tools includes assessing therapeutic response [6-8], detecting subclinical mucosal inflammation [9-13] and predicting disease relapse $[14,15]$

Both CRP and FC are linked with the tumor necrosis factor- $\alpha(\mathrm{TNF} \alpha)$ pathway which plays an integral part in the pathogenesis of gut inflame- mation. Data from experimental models shows that calprotectin stimulates the increase of $\mathrm{TNF} \alpha$ secretion which, in turn, induces hepatic synthesis of proinflammatory cytokines including CRP [1619]. The importance of TNF $\alpha$-driven response in IBD is underlined by the efficiency of antiTNF $\alpha$ biologic agents in inducing and maintaining disease remission [20]. Despite the wide use of antiTNFs for the treatment of IBD, data regarding the diagnostic and prognostic accuracy of serum TNF $\alpha$ levels is conflicting $[21,22]$.

The aim of this study was to evaluate the diagnostic and prognostic accuracy of $\mathrm{FC}$, serum CRP and TNFa in a cohort of ulcerative colitis patients.

\section{MATERIALS AND METHODS}

\section{PATIENTS}

Consecutive patients with a confirmed diagnosis of ulcerative colitis from the Multimodal Approach in Inflammatory Bowel Disease (MAID) cohort 
were included in this analysis. Briefly, this prospective observational study of IBD patients at "Colentina" Clinical Hospital (NCT01705522) includes ulcerative colitis and Crohn's disease patients over 18 years of age, irrespective of disease location, clinical activity or medication. The study was conducted according to the principles of the Declaration of Helsinki (1975, last revised 2008). Study design was approved by the local ethics committee and all patients signed an informed consent form prior to study enrollment.

At enrollment a detailed history was obtained, current and past medication for IBD was reviewed and patients underwent a complete physical examination. Colonoscopy was performed using EXERA II 180 series Olympus colonoscopes by endoscopists with experience in IBD and the Mayo endoscopy score [23] was noted for each patient.

Scheduled study visits that included physical examination, serum and fecal biomarker assessment and colonoscopy were carried out at 12 month intervals when data about disease relapse and/or disease-related complications (i.e. - surgery) was also obtained.

\section{DISEASE ACTIVITY AND FOLLOW-UP}

Disease activity was assessed using the Mayo score; patients with a score of 2 or less were considered to be in clinical remission. Endoscopic activity was defined by an endoscopic Mayo subscore of at least 1 and disease extension was evaluated according to the Montreal classification [24].

\section{BIOMARKER ASSESSMENT}

Serum and fecal samples obtained prior to colonoscopy at each scheduled study visit were stored at $-80^{\circ} \mathrm{C}$.

Fecal calprotectin levels were determined using the Buhlmann Quantum Blue Reader ${ }^{\circledR}$. This is a fast and accessible point-of-care method for determining calprotectin levels in the range of 30$300 \mu \mathrm{g} / \mathrm{g}$. Serum levels of TNF $\alpha$ were determined using sandwich ELISA kit from Immunodiagnostik (Bensheim, Germany) according to the manufacturer's instructions. All samples were assayed in duplicate. The absorbance was then measured at $450 \mathrm{~nm}$ on a spectrophotometer (Biorad Hercules, CA, USA)

Serum levels of $\mathrm{C}$ reactive protein (CRP) were measured using an immunoturbidimetric assay (Abbott Clinical Chemistry Diagnostics, Illinois, USA).

\section{OUTCOME MEASURES}

The main outcome measures for this study were clinical and endoscopic remission at 12 months follow-up.

\section{DATA COLLECTION AND ANALYSIS}

Results are expressed as frequencies for categorical variables (further analyzed by Fisher's exact test), mean and standard deviation for normal continuous variables (analyzed by Student's $t$ test), and median and extremes for non-normal continuous variables (analyzed by the Mann-Whitney $U$ and Kruskall Wallis tests). Each biomarker (CRP, fecal calprotectin and $\mathrm{TNF} \alpha$ ) was individually evaluated as a diagnostic test for clinical and endoscopic disease activity; area under the receiver operator characteristic curve (AUROC) was calculated as well as sensitivity $(\mathrm{Sn})$ and specificity $(\mathrm{Sp})$ with 95\% confidence intervals (95\% CI). Multivariate analysis was conducted using linear regression to evaluate the interaction between different biomarkers while adjusting for cofactors. Hypothesis testing was 2-tailed, with $\mathrm{p}<0.05$ considered statistically significant. The statistical software package SPSS for Windows Version 16.0 (SPSS Inc., Chicago, IL) was used to analyze the data.

\section{RESULTS}

Fifty-three ulcerative colitis patients (23 female, mean age 37) were included in the study and followed for a median of 12 months (range 624 months), between November 2012 and February 2015, accounting for a total of 92 study visits (median 2, range 1-3). At baseline evaluation, 37 patients had clinically active disease with a Mayo score of at least 3 and 48 had active inflammation at endoscopy, with a Mayo sub-score of at least 1 . The baseline characteristics of the included subjects are detailed in Table I. Clinical and endoscopic evaluation as well as serum samples were available for all visits, but only 63 out of 92 fecal samples provided were sufficient for analysis.

\section{BIOMARKER ACCURACY IN DETECTING CLINICALLY ACTIVE DISEASE}

CRP levels and FC levels were significantly higher in patients with clinically active disease than in patients in remission, but no difference was 
observed for serum TNF $\alpha$ levels (Table II). At a cut-off of $300 \mu \mathrm{g} / \mathrm{g}$ FC had a $67 \%$ Sn $(95 \%$ CI 50 $81 \%$ ) and $70 \% \mathrm{Sp}(95 \% \mathrm{CI} 49-87 \%)$ in diagnosing clinically active UC, with an AUROC of 0.72 (CI $95 \% 0.58-0.86$ ). At a cut-off value of $5 \mathrm{mg} / \mathrm{L}$ CRP had a $57 \%$ Sn (95\% CI $42-71 \%)$ and $88 \%$ Sp $(95 \%$ CI $72-96 \%$ ) for diagnosing clinically active UC, with an AUROC of 0.76 (95\% CI 0.66-0.86).

\section{BIOMARKER ACCURACY IN DETECTING ENDOSCOPIC ACTIVITY}

Median FC levels were significantly increased in patients with ulcerative colitis who had endoscopically active disease compared to patients with mucosal healing $(300 \mu \mathrm{g} / \mathrm{g} v \mathrm{~s} .30 \mu \mathrm{g} / \mathrm{g}, \mathrm{p}=0.001$ Mann Whitney U). As a diagnostic test for mucosal inflammation, FC performed well, with an estimated AUROC of 0.79 (95\% CI 0.61-0.98). At a cut-off value of $300 \mu \mathrm{g} / \mathrm{g}$ FC had a $90 \% \mathrm{Sp}(95 \%$ CI $55-$ $98 \%$ ) and a $60 \%$ Sn (95\% CI 46-75\%), with a positive predictive value of $96 \%$ (95\% CI 83-99\%).

None of the serum biomarkers correlated significantly with endoscopic disease activity (Table II).

\section{BIOMARKER ACCURACY IN PREDICTING DISEASE COURSE}

Clinical and endoscopic disease activity at 12 months follow-up were available for a total of 43 study subjects. Of these patients, 25 were in clinical remission (58\%) but only $11(26 \%)$ had mucosal healing at endoscopy. Serum and fecal biomarker levels did not differ significantly at baseline between patients who were in clinical remission at 12 months compared to patients with active disease at follow-up.

However, baseline fecal calprotectin levels were significantly higher in patients who had active endoscopic disease compared to those of patients showing mucosal healing at follow-up $(300 \mu \mathrm{g} / \mathrm{g}$ vs. $37 \mu \mathrm{g} / \mathrm{g}, \mathrm{p}=0.01$ Mann Whitney U) (Figure 1). At a cut-off value of $300 \mu \mathrm{g} / \mathrm{g}$ FC had a $61 \% \mathrm{Sn}$ (95\% CI $38.5-80 \%)$ and a $89 \%$ Sp (95\% CI $52-$ $98 \%$ ) for predicting mucosal healing at follow-up, with a positive predictive value of $93 \%$ (95\% CI 68-98\%) and an AUROC of 0.79 (95\% CI 0.610.97) (Figure 2). Patients with a calprotectin level of $300 \mu \mathrm{g} / \mathrm{g}$ or higher had an OR of $12.4(95 \% \mathrm{CI}$ 1.3-117) of having active mucosal inflammation at follow-up endoscopy.

None of the serum biomarkers were able to predict either clinical or endoscopic activity at follow-up (Table III).

\section{MULTIVARIATE ANALYSIS}

There was no statistically significant correlation between the levels of any serum or feces biomarkers at univariate analysis. On multivariate analysis with linear regression, using the other biomarkers and the type of treatment as covariates, there was no significant interaction between the biomarkers.

Table I

Baseline characteristics of the study group including on-going medication

\begin{tabular}{|c|c|}
\hline Gender (female / total) & $23 / 53$ \\
\hline Age (mean, SD) & $37(10)$ \\
\hline \multicolumn{2}{|l|}{ Disease extension } \\
\hline Proctitis & $9(17 \%)$ \\
\hline Left-sided colitis & $12(22 \%)$ \\
\hline Extended colitis & $32(61 \%)$ \\
\hline Clinical activity at baseline & $35(66 \%)$ \\
\hline Median Mayo clinical score (range) & $3(0-11)$ \\
\hline Endoscopic activity at baseline & $47(89 \%)$ \\
\hline Median Mayo endoscopic score (range) & $1(0-3)$ \\
\hline \multicolumn{2}{|l|}{ Patient medication at baseline } \\
\hline Corticosteroids & $8(15 \%)$ \\
\hline 5 Aminosalicylates & $32(61 \%)$ \\
\hline Thiopurines & $5(9 \%)$ \\
\hline Anti TNFa & $9(17 \%)$ \\
\hline
\end{tabular}

TNF - tumor necrosis factor $\alpha$; SD - standard deviation 
Table II

Comparison of of inflammatory biomarkers levels in ulcerative colitis patients according to clinical and endoscopic disease activity

\begin{tabular}{lcccccc}
\hline \multicolumn{1}{c}{ Biomarker } & Clinical activity & Remission & $\mathbf{p}$ & Endoscopic activity & Mucosal healing & $\mathbf{p}$ \\
\hline CRP $\mathbf{~ m g} / \mathbf{L}$ & $6.5(0-122)$ & $2(0.1-12.9)$ & $<\mathbf{0 . 0 0 1}$ & $3.9(0-122)$ & $1.9(0.5-12.9)$ & 0.11 \\
FC $\boldsymbol{\mu} \mathbf{g} / \mathbf{g}$ & $300(30-300)$ & $97(30-300)$ & $\mathbf{0 . 0 0 2}$ & $300(30-300)$ & $30(30-300)$ & $\mathbf{0 . 0 0 1}$ \\
TNF $\boldsymbol{\alpha} \mathbf{~} \mathbf{~ g} / \mathbf{m L}$ & $2.9(0-1439)$ & $3(0-364)$ & 0.8 & $2.3(0-1440)$ & $8.8(0-271)$ & 0.16 \\
\hline
\end{tabular}

CRP - C-reactive protein; FC - fecal calprotectin; TNF $\alpha$ - tumor necrosis factor $\alpha$; ${ }^{\boldsymbol{I}}$ statistically significant, $\mathrm{p}<0.05$ using Mann Whitney U

Table III

Comparison of serum and fecal biomarker levels according to patient outcome at follow-up

\begin{tabular}{lccccccc}
\hline \multicolumn{1}{c}{ Biomarker } & Active disease & Remission & P & Endoscopic activity & Mucosal healing & p \\
\hline CRP $\mathbf{~ m g} / \mathbf{L}$ & $4.4(1-122)$ & $6(0.2-66)$ & 0.6 & $4.2(0.2-122)$ & $8.8(0.8-19)$ & 0.8 \\
FC $\boldsymbol{\mu g} / \mathbf{g}$ & $300(30-300)$ & $210(30-300)$ & 0.3 & $300(30-300)$ & $37(30-300)$ & $\mathbf{0 . 0 1}$ \\
TNF $\boldsymbol{\alpha} \mathbf{~ p g} / \mathbf{m L}$ & $2.6(0-657)$ & $3(0-411)$ & 0.9 & $0.6(0-657)$ & $8.8(0-411)$ & 0.17 \\
\hline
\end{tabular}

CRP - C-reactive protein; FC - fecal calprotectin; TNF $\alpha$ - tumor necrosis factor $\alpha$; ${ }^{\text {『 }}$ statistically significant - Mann Whitney U

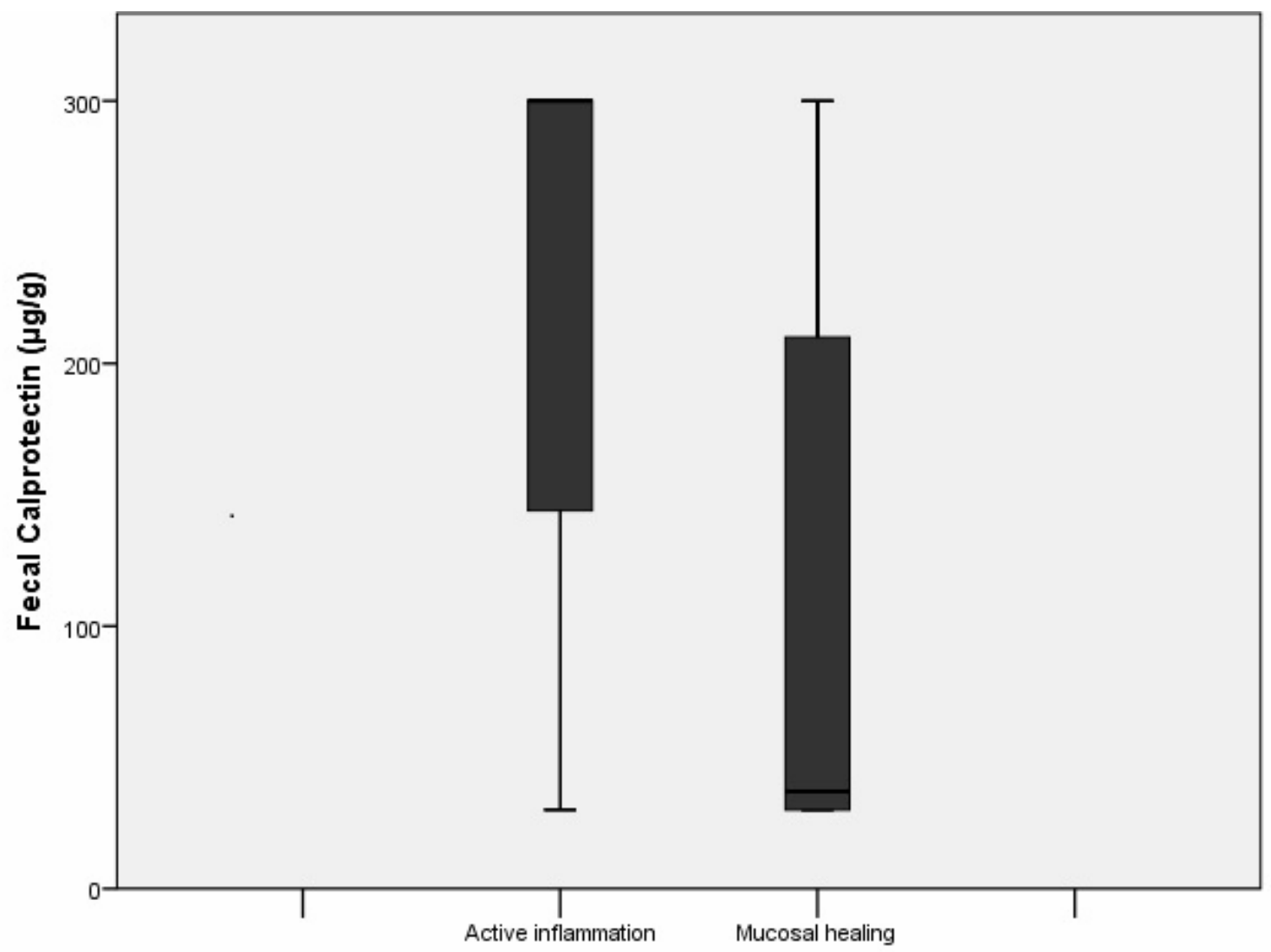

Endoscopic activity at follow-up

Figure 1. Baseline fecal calprotectin levels in patients with mucosal healing at 12 months follow-up compared to those with active endoscopic activity (median values $37 \mu \mathrm{g} / \mathrm{g}$

and $300 \mu \mathrm{g} / \mathrm{g}, \mathrm{p}=0.01$ Mann Whitney $U$ ). 


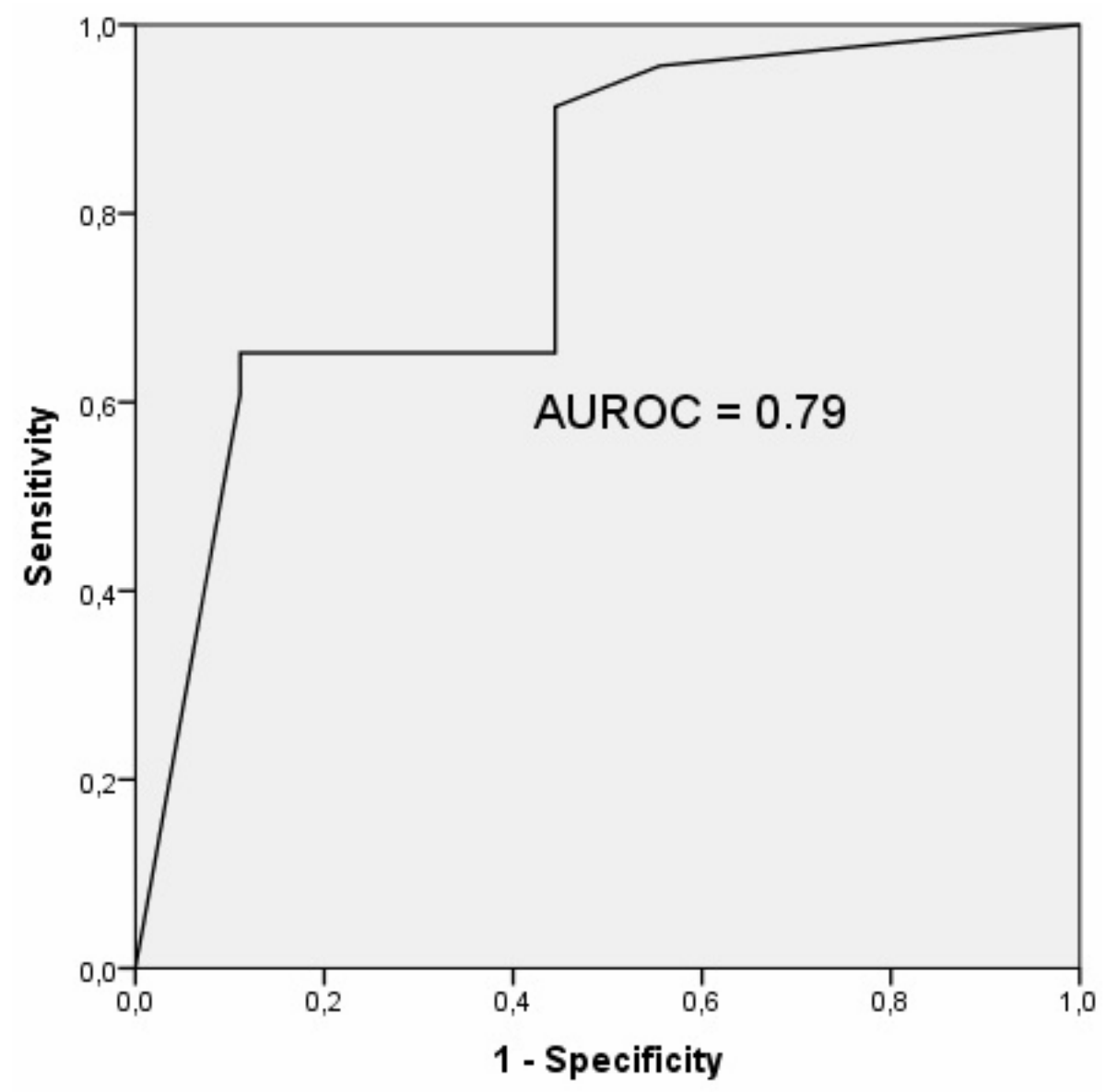

Figure 2. Area under the receiver-operator characteristic (AUROC) for rapid fecal calprotectin testing as a predictor of mucosal healing at 12 months follow-up.

\section{DISCUSSION}

This study shows that rapid FC testing can accurately detect mucosal inflammation and predict mucosal healing in UC patients and it is a better diagnostic and predictive tool than serum biomarkers such as CRP and TNF $\alpha$.

Developing diagnostic and predictive instruments based on serum and fecal biomarkers is an important challenge in the management of UC patients. Current guidelines rely mainly on clinical and endoscopic scores (i.e. the Mayo score) for assessing disease severity and predicting disease course in UC patients, and so far noninvasive biomarkers such as CRP or fecal calprotectin have found only limited use as either diagnostic or predictive markers $[25,26]$. Recent studies have focused on biomarker discovery and validation [27], as well as finding new ways to combine noninvasive tests to increase diagnostic and predictive accuracy in IBD $[28,29]$. The investigation of various cytokines involved in the TNF $\alpha$ inflamematory cascade is a promising endeavor since
antiTNF agents acting on this pathway represent one of the mainstays of therapy in IBD [22, 30-32]. Among these various markers, FC has emerged as a valuable diagnostic and prognostic biomarker, although it remains unclear how this tool will be integrated in everyday practice.

An important advantage of our study is the fact that we have employed a simple semi-quantitative method for determining FC levels in the stool of UC patients. This point-of-care method for determining $\mathrm{FC}$ has been been compared with ELISA-based methods with satisfying results [33] but it is less costly and readily available in the physician's office. Our results validate earlier data from a pilot study of both Crohn's disease and UC patients showing a good accuracy for rapid FC in detecting active mucosal inflammation in IBD patients in clinical remission [34].

Both rapid FC levels and CRP correlated with clinical disease activity, however only FC accurately predicted endoscopic activity both at baseline and at follow-up. This finding can be explained by the fact that FC seems a better indicator of mucosal 
inflammation than serum biomarkers, including CRP [35-37]. Moreover, FC can also predict important disease-related outcomes such as relapse or response to therapy [38].

In contrast, serum TNFa levels did not correlate with either disease activity or CRP and $\mathrm{TNF} \alpha$ levels, irrespective of antiTNF treatment. Up-to-date studies evaluating the correlation between $\mathrm{TNF} \alpha$ levels and disease activity or response to treatment have shown conflicting results, suggesting a wide variation of biomarker levels in both TNF $\alpha$ treated and naïve patients [39-41]. Also, several studies analyzing biomarker panels consisting of proinflammatory serum cytokines have failed to show a correlation between TNF levels and disease activity or other biomarker levels, despite the widely accepted notion that TNF is central to the inflammatory process in IBD $[21,42]$.

The main limitations of our study are the limited cohort size and the relatively low compliance of patients in returning sufficient fecal samples. However, this appraisal of a cohort of consecutive patients with UC reflects the real-life setting of managing IBD patients and has the advantage of an adequate follow-up period. The data from our study is consistent with previous research and supports the use of simple, point-of- care tests such as rapid FC for an easy and accurate assessment of mucosal inflammation.

An important question that still needs to be addressed is the optimal cut-off for FC. In our study FC levels above $300 \mu \mathrm{g} / \mathrm{g}$ correlated well with endoscopic activity at baseline and were also accurate in predicting mucosal healing at 12 months. Using an ELISA-based method but the same threshold value for FC, De Vos also showed high specificity in predicting disease activity at 12 months [43]. However, other studies with different patient populations and outcome measures have proposed different cut-off values for FC [10, 34, 45]. It is likely that cut-off values need to be further explored according to the particular setting in which the test is used - i.e. for diagnosing IBD versus assessing disease activity in a patient with a confirmed diagnosis.

In conclusion, this study shows that FC provides better diagnostic and prognostic accuracy than serum biomarkers, and it should become a routine test in the management of UC patients, thus reducing the need for invasive investigations such as colonoscopy.

Acknowledgement. This research was partly supported by a Young Researcher Grant from the Carol Davila School of Medicine (Tineri Cercetători TC 2013 / 28339).

Introducere. Biomarkerii serici şi fecali au un rol în evaluarea noninvazivă a activității bolii la pacienții cu colită ulcerativă. Proteina $C$ reactivă, factorul de necroză tumorală alfa şi calprotectina fecală se numără printre cei mai promițători asemenea markeri. $\mathrm{Cu}$ toate acestea, rolul lor în managementul pacienților $\mathrm{cu}$ colită ulcerativă este incomplet definit.

Obiective. Ne-am propus evaluarea acurateții diagnostice a proteinei $C$ reactive, calprotectinei fecale şi TNF $\alpha$ in detecția activității clinice şi endoscopice precum şi în predicția evoluției pacienților cu colită ulcerativă.

Metode. Am evaluat prospectiv activitatea clinică şi endoscopică a bolii într-o cohortă de pacienți cu colită ulcerativă folosind scorul Mayo. Am măsurat nivelurile serice ale PCR şi TNF $\alpha$ şi am cuantificat calprotectina fecală folosind o metodă rapidă semicantitativă.

Rezultate. 53 de pacienți cu colită ulcerativă au fost urmăriți pe o durată medie de 12 luni de zile. Calprotectina şi PCR au fost semnificativ mai mari la pacienții cu boală clinic activă la înrolare dar numai calprotectina fecală s-a corelat cu activitatea clinică. Valori ale calprotectinei peste $300 \mu \mathrm{g} / \mathrm{g}$ au avut o sensibilitate de $60 \%$ şi o specificitate de $90 \%$ in detectarea activității endoscopice şi o sensibilitate de $61 \%$ cu o specificitate de $89 \%$ in predicția vindecării mucosale.

Concluzii. Determinarea semicantitativă a proteinei fecale este un predictor superior al vindecării mucosale comparativ cu markerii serici ş̧i ar putea îmbunătăți managementul pacienților cu colită ulcerativă prin scăderea necesarului de examinări endoscopice invazive.

Correspondence to: Theodor Voiosu, Gastroenterology Division, "Colentina" Clinical Hospital, 19-21 Ştefan cel Mare Bvd., Bucharest, Romania, Tel.: 0040213180604

E-mail: theodor.voiosu@gmail.com 


\section{REFERENCES}

1. CIOFFI M, ROSA AD, SERAO R, et al. Laboratory markers in ulcerative colitis: Current insights and future advances. World J Gastrointest Pathophysiol. 2015; 6(1):13-22.

2. MENDOZA JL, ABREU MT. Biological markers in inflammatory bowel disease: practical consideration for clinicians. Gastroenterol Clin Biol. 2009; 33 Suppl 3:S158.

3. HENRIKSEN M, JAHNSEN J, LYGREN I, et al. C-reactive protein a predictive factor and marker of inflammation in inflammatory bowel disease. Results from a prospective population-based study. Gut. 2008; 57(11):1518-23.

4. VAN RHEENEN PF, VAN DE VIJVER E, FIDLER V. Faecal calprotectin for screening of patients with suspected inflammatory bowel disease: diagnostic meta-analysis. BMJ 2010; 341:c3369.

5. VON ROON AC, KARAMOUNTZOS L, PURKAYASTHA S, et al. Diagnostic precision of fecal calprotectin for inflammatory bowel disease and colorectal malignancy. Am J Gastroenterol 2007; 102: 803- 813.

6. TRAVIS SP, FARRANT JM, RICKETTS C, et al. Predicting outcome in severe ulcerative colitis. Gut 1996; 38:905-910.

7. BOSCHETTI G, GARNERO P, MOUSSATA D, et al. Accuracies of Serum and Fecal S100 Proteins (Calprotectin and Calgranulin C) to Predict the Response to TNF Antagonists in Patients with Crohn's Disease. Inflamm Bowel Dis. 2015; 21(2):331-6.

8. KISS LS, SZAMOSI T, MOLNAR T, et al. Early clinical remission and normalisation of CRP are the strongest predictors of efficacy, mucosal healing and dose escalation during the first year of adalimumab therapy in Crohn's disease. Aliment Pharmacol Ther. 2011; 34(8):911-22.

9. MOOIWEER E, SEVERS M, SCHIPPER ME, et al. Low fecal calprotectin predicts sustained clinical remission in inflammatory bowel disease patients: a plea for deep remission. J Crohns Colitis. 2015; 9(1):50-5.

10. D'HAENS G, FERRANTE M, VERMEIRE S, et al. Fecal calprotectin is a surrogate marker for endoscopic lesions in inflammatory bowel disease. Inflamm Bowel Dis. 2012; 18(12):2218-24.

11. SCHOEPFER AM, BEGLINGER C, STRAUMANN A, et al. Ulcerative colitis: correlation of the Rachmilewitz endoscopic activity index with fecal calprotectin, clinical activity, C-reactive protein, and blood leukocytes. Inflamm Bowel Dis 2009; 15: 1851-1858.

12. SIPPONEN T, KÄRKKÄINEN P, SAVILAHTI E, et al. Correlation of faecal calprotectin and lactoferrin with an endoscopic score for Crohn's disease and histological findings. Aliment Pharmacol Ther 2008; 28: 1221- 1229.

13. FROSLIE KF, JAHNSEN J, MOUM BA, et al. Mucosal healing in inflammatory bowel disease: results from a Norwegian population-based cohort. Gastroenterology 2007; 133:412-22.

14. COSTA F, MUMOLO MG, CECCARELLI L, et al. Calprotectin is a stronger predictive marker of relapse in ulcerative colitis than in Crohn's disease. Gut. 2005; 54(3):364-8.

15. NAISMITH GD, SMITH LA, BARRY SJ, et al. A prospective evaluation of the predictive value of faecal calprotectin in quiescent Crohn's disease. J Crohns Colitis. 2014; 8(9):1022-9.

16. CESARO A, ANCERIZ N, PLANTE A, et al. An inflammation loop orchestrated by S100A9 and calprotectin is critical for the development of arthritis. PLoS One. 2012; 7(9): e45478.

17. FEGHALI CA, WRIGHT TM. Cytokines in acute and chronic inflammation. Front Biosci. 1997 1; (2):d12-26.

18. VERMEIRE S, VAN ASSCHE G, RUTGEERTS P.C-reactive protein as a marker for inflammatory bowel disease. Inflamm Bowel Dis. 2004; 10(5):661-5.

19. VATAY A, BENE L, KOVÁCS A, et al. Relationship between the tumor necrosis factor alpha polymorphism and the serum Creactive protein levels in inflammatory bowel disease. Immunogenetics. 2003; 55(4):247-52.

20. COLOMBEL JF, RUTGEERTS P, REINISCH W, et al. Early mucosal healing with infliximab is associated with improved longterm clinical outcomes in ulcerative colitis. Gastroenterology 2011; 141:1194-201.

21. FENG JS, YANG Z, ZHU YZ, et al. Serum IL-17 and IL-6 increased accompany with TGF- $\beta$ and IL-13 respectively in ulcerative colitis patients. Int J Clin Exp Med. 2014; 7(12):5498-504.

22. OWCZAREK D, CIBOR D, GLOWACKI MK, et al. TNF- $\alpha$ and soluble forms of TNF receptors 1 and 2 in the serum of patients with Crohn's disease and ulcerative colitis. Pol Arch Med Wewn. 2012; 122(12):616-23.

23. SCHROEDER KW, TREMAINE WJ, ILSTRUP DM. Coated oral 5-aminosalicylic acid therapy for mildly to moderately active ulcerative colitis. A randomized study. N Engl J Med 1987; 317: 1625-9.

24. VAN ASSCHE G, DIGNASS A, PANES J, et al. European Crohn's and Colitis Organisation (ECCO). The second European evidence-based Consensus on the diagnosis and management of Crohn's disease: Definitions and diagnosis. J Crohns Colitis. 2010; 4(1):7-27

25. DIGNASS A, ELIAKIM R, MAGRO F, et al. Second European evidence-based consensus on the diagnosis and management of ulcerative colitis part 1: definitions and diagnosis. J Crohns Colitis. 2012; 6(10):965-90.

26. SCHOEPFER AM, VAVRICKA S, ZAHND-STRAUMANN N, et al. Monitoring infammatory bowel disease activity: clinical activity is judged to be more relevant than endoscopic severity or biomarkers. J Crohns Colitis 2012; 6:412-418.

27. RODA G, CAPONI A, BENEVENTO M, et al. New proteomic approaches for biomarker discovery in inflammatory bowel disease. Inflamm Bowel Dis. 2010; 16(7):1239-46.

28. FAUBION WA JR1, FLETCHER JG, O'BYRNE S, et al. EMerging BiomARKers in Inflammatory Bowel Disease (EMBARK) study identifies fecal calprotectin, serumMMP9, and serum IL-22 as a novel combination of biomarkers for Crohn's disease activity: role of cross-sectional imaging. Am J Gastroenterol. 2013; 108(12):1891-900.

29. DE VOS M, LOUIS EJ, JAHNSEN J, et al. Consecutive fecal calprotectin measurements to predict relapse in patients with ulcerative colitis receiving infliximab maintenance therapy. Inflamm Bowel Dis. 2013; 19(10):2111.

30. SCHMIDT C, GIESE T, HERMANN E, et al. Predictive value of mucosal TNF-alpha transcripts in steroid-refractory Crohn's disease patients receiving intensive immunosuppressive therapy. Inflamm Bowel Dis. 2007;13(1):65-70. 
31. DIONNE S, HISCOTT J, D'AGATA I et al. Quantitative PCR analysis of TNF-alpha and IL-1 beta mRNA levels in pediatric IBD mucosal biopsies. Dig Dis Sci. 1997; 42(7):1557-66.

32. MARTÍNEZ-BORRA J, LÓPEZ-LARREA C, GONZÁLEZ S, et al. High serum tumor necrosis factor-alpha levels are associated with lack of response to infliximab in fistulizing Crohn's disease. Am J Gastroenterol. 2002; 97(9):2350-6.

33. SYDORA MJ, SYDORA BC, FEDORAK RN. Validation of a point-of-care desk top device to quantitate fecal calprotectin and distinguish inflammatory bowel disease from irritable bowel syndrome. J Crohns Colitis. 2012; 6(2):207-14

34. VOIOSU T, BENGUŞ A, DINU R, et al. Rapid fecal calprotectin level assessment and the SIBDQ score can accurately detect active mucosal inflammation in IBD patients in clinical remission: a prospective study. J Gastrointestin Liver Dis. 2014; 23(3):273-8.

35. SCHOEPFER AM, BEGLINGER C, STRAUMANN A, et al. Fecal calprotectin correlates more closely with the Simple Endoscopic Score for Crohn's disease (SES-CD) than CRP, blood leukocytes, and the CDAI. Am J Gastroenterol 2010; 105: 162-169.

36. YOON JY, PARK SJ, HONG SP et al. Correlations of C-reactive protein levels and erythrocyte sedimentation rates with endoscopic activity indices in patients with ulcerative colitis. Dig Dis Sci. 2014; 59(4):829-37.

37. SCHOEPFER AM, BEGLINGER C, STRAUMANN A, et al. Fecal calprotectin more accurately reflects endoscopic activity of ulcerative colitis than the Lichtiger Index, C-reactive protein, platelets, hemoglobin, and blood leukocytes. Inflamm Bowel Dis. 2013; 19(2):332-41.

38. LEWIS JD. The utility of biomarkers in the diagnosis and therapy of inflammatory bowel disease. Gastroenterology. 2011; 140(6):1817-1826.

39. MARTÍNEZ-BORRA J, LÓPEZ-LARREA C, GONZÁLEZ S, et al. High serum tumor necrosis factora are associated with lack of response to infliximab in fistulizing Crohn's disease. Am J Gastroenterol 2002; 97(9):2350-6.

40. OLSEN T, GOLL R, CUI G et al. Tissue levels of tumor necrosis factor-alpha correlates with grade of inflammation in untreated ulcerative colitis. Scand J Gastroenterol. 2007; 42(11):1312-20.

41. KOMATSU M, KOBAYASHI D, SAITO K. Tumor necrosis factor-alpha in serum of patients with inflammatory bowel disease as measured by a highly sensitive immuno-PCR. Clin Chem. 2001; 47(7):1297-301.

42. RODRÍGUEZ-PERÁLVAREZ ML, GARCÍA-SÁNCHEZ V, VILLAR-PASTOR CM, et al. Role of serum cytokine profile in ulcerative colitis assessment. Inflamm Bowel Dis. 2012; 18(10):1864-71.

43. DE VOS M, LOUIS EJ, JAHNSEN J, et al. Consecutive fecal calprotectin measurements to predict relapse in patients with ulcerative colitis receiving infliximab maintenance therapy. Inflamm Bowel Dis. 2013; 19(10):2111-7.

44. GARCÍA-SÁNCHEZ V, IGLESIAS-FLORES E, GONZÁLEZ R, et al. Does fecal calprotectin predict relapse in patients with Crohn's disease and ulcerative colitis? J Crohns Colitis. 2010; 4(2):144-52.

Received May 31, 2015 